Asian J. Med. Biol. Res. 2018, 4 (1), 63-68; doi: 10.3329/ajmbr.v4i1.36823

\author{
Asian Journal of \\ Medical and Biological Research \\ ISSN 2411-4472 (Print) 2412-5571 (Online) \\ www.ebupress.com/journal/ajmbr
}

\title{
Article \\ Productive and reproductive performances of Sheep at field level of Rajshahi and Mymensingh District of Bangladesh
}

\author{
Md. Abdullah Al Mansur ${ }^{1 *}$, Md. Golam Shahi Alam ${ }^{1}$, Pankaj Kumar Jha ${ }^{1,2}$, Md. Asaduzzaman Rimon ${ }^{1}$, Nazmun \\ Naher ${ }^{1}$ and Farida Yeasmin Bari ${ }^{1}$ \\ ${ }^{1}$ Department of Surgery and Obstetrics, Bangladesh Agricultural University, Mymensingh, Bangladesh \\ ${ }^{2}$ Nepal Agricultural Research Council (NARC), Khumaltar, Lalitpur, P.O. Box: 1950, Kathamndu, Nepal \\ *Corresponding author: Md. Abdullah Al Mansur, DVM (PSTU), MS, Bangladesh Agricultural University, \\ Mymensingh, Bangladesh, Phone: +8801723205705, Email: mansur_dvm@yahoo.com
}

Received: 04 March 2018/Accepted: 19 March 2018/ Published: 29 March 2018

\begin{abstract}
This study was undertaken to assess the reproductive performances of sheep at field level of Rajshahi and Mymensingh district of Bangladesh during January to December, 2016. A total of 52 farms (26 each in Rajshahi and Mymensingh) were selected for determining the reproductive parameters of ewes. Ewe lambs in Mymensingh reached puberty at significantly $(\mathrm{P}<0.03)$ younger age $(186.9 \pm 18.4$ days $)$ than in Rajshihi (199.9 \pm 24.9 days). The average age at first pregnancy was $201.4 \pm 20.0$ days in two regions. Similarly, the ewes in Mymensingh was lambing at significantly $(\mathrm{P}<0.002)$ early age than ewes in Rajshahi $(356.0 \pm 6.8$ days vs. $372.7 \pm 27.8$ days). The observed duration of oestrus at Rajshahi and Mymensingh was 36.0 \pm 6.7 hrs and $36.0 \pm 7.3 \mathrm{hrs}$, respectively. The gestation length varied from 145 to 150 days. The average gestation length was $147.9 \pm 3.4$ days in two regions. The gestation length was not significant $(\mathrm{P}>0.05)$ in the ewes between Rajshahi and Mymensingh (148.7 \pm 3.4 and 147.1 \pm 3.2 days; respectively). The pooled over litter size was $1.6 \pm 0.2$ in two regions. However, there was no significant $(\mathrm{P}>0.05)$ difference in litter size of ewes in Rajshahi and Mymensingh region (1.7 \pm 0.2 vs. $1.6 \pm 0.2)$. The pooled lambing interval was $193.9 \pm 21.7$ days in two regions. Mean birth weights of lambs, weaning weight and mature weight were $1.7 \pm 0.6$ vs. $1.3 \pm 0.1 \mathrm{~kg} ; 8.9 \pm 2.7$ vs. $6.9 \pm 1.0 \mathrm{~kg}$ and $24.9 \pm 7.3$ vs. $19.4 \pm 2.7 \mathrm{~kg}$ in Rajshahi and Mymensingh, respectively. These reproductive parameters were significantly higher $(\mathrm{P}<0.001)$ in Rajshahi compared with in Mymensingh. The reproductive parameters are almost similar between confined and the traditional management system if the farms are well managed.
\end{abstract}

Keywords: productive; reproductive; performance; sheep; field level

\section{Introduction}

Sheep is one of the important livestock species of mixed farming system in Bangladesh. Sheep are the basic livelihood option for the poor farmers in developing countries like Bangladesh. It provides nutritional security, employment and income generation. The sheep population has shown to be in increasing trend with 2.5 times during the last twelve years with annual growth rate of 5\% (Sarket et al., 2015). The total sheep population in Bangladesh is 3.3 million (DLS, 2016). Sheep rearing is common in Bangladesh with major percentage about, $32 \%$ are reared in three ecological zones namely Barind, Jamuna basin and Coastal areas. Bangladeshi sheep are indigenous, with few crossbreds (Bhuiyan, 2006) and are capable of bi-annual lambing with multiple births; usually produce twins and rarely triplets. The hot and humid climate of Bangladesh favors well adaptation for these indigenous sheep. They reached in puberty at 5-11 months of age, estrus cycle length varied from 14 to 20 days (average 17 days), duration of estrus varied from 24 to 36 hours, gestation length varied from 141 to 145 days and litter size varied from 1.2 to 1.9 observed under close monitoring in research station (Zohara et al., 2014; Hassan and Talukder, 2011). Despite of these positive prosperities, farmers are not aware with modern 
husbandry-veterinary practices and controlled breeding schemes for profitable sheep farming. There are mainly two downstream in sheep breeding at farmers level; first - the farmers castrate their male at early age for getting current profit resulting falls of breeding rams and second - farmers use same ram for breeding year after year which increases inbreeding. Beside these, farmers are lack of breeding and management information practices about reproductive and productive benefits from sheep farming. Therefore the present research was performed to study the reproductive performances of sheep maintained in traditional management system at field level in Rajshahi and Mymensingh district of Bangladesh.

\section{Materials and Methods}

\subsection{Study area and farm selection}

The study was carried out in some sheep farms at Rajshahi and Mymensingh division in Bangladesh. The study was conducted from January to December, 2016. Sheep farmer's information was taken from the district livestock officer and a total of 52 farms ( 26 farms in each division) farms were randomly selected within those areas.

\subsection{Animal management in the farm}

Sheep flocks in the selected area were reared in their traditional management system. Early in the morning, sheep were pastured in the mango garden or open paddy field or open grass land. They were kept in the pasture land for the duration of whole day and came back during sundown. Few farmers fed concentrate feed after returning at home. Some good farmers maintained proper vaccination and deworming schedule. Necessary treatments were given against specific diseases according to the suggestion of the veterinary surgeons.

\subsection{Data collection}

A well-structured data sheet was prepared before data collection. The selected farms were visited personally. The information was collected by face to face interview with the farm owner and animal caretaker. The information included parameters for reproductive performances were as follows: age at 1 st heat, weight at 1 st heat, duration of estrus, gestation length, age at first pregnancy, age at first lambing, lambing interval, onset of post partum heat, post partum heat period, litter size, birth weight of lamb, weaning weight and mature weight.

\subsubsection{Age at $1^{\text {st }}$ heat or puberty}

The age at puberty was estimated as the age in days when ewes exhibited the sign of first estrus, by observing wagging tail, swelling and mucus discharge from the vulva, jumping tendency to others, rubbing their body with the rams and remain closer to the rams.

\subsubsection{Weight at $1^{\text {st }}$ heat}

This trait was estimated in terms of $\mathrm{kg}$ when the ewes come in heat with the help of weighing balance.

\subsubsection{Measurement of oestrous cycle length and duration}

Estrous detection in ewes was carried out by the observation of estrus sign by the farmer or animal caretaker. Oestrus duration was determined by measuring the time interval between the onset of oestrus and when a ewe no longer stood to be mounted.

\subsubsection{Length of gestation period}

It was calculated as the interval from fertile service to parturition. Gestation length was counted from the day of service to the day of onset of labour. The duration of gestation was determined in days.

\subsubsection{Age at first lambing}

Age at first lambing was estimated in days from the date of birth to the date of first lambing.

\subsubsection{Lambing interval}

Lambing interval was determined by measuring the interval between the dates of one lambing to the date of next lambing. The lambing interval was recorded in days.

\subsubsection{Litter size}

Litter size was calculated as the number of lambs born per conception per ewe.

Litter size was calculated by the following formula: 
Litter size $($ prolificacy $)=$ number of lambs / number of ewes lambing

\subsubsection{Post-partum onset of oestrus}

Post-partum onset of oestrus was determined by the first observed oestrus after parturition.

\subsubsection{Lamb birth weight, weaning weight and mature weight}

Within 24 hours of the new born, date of birth, birth weight, type of birth, sex of lamb was taken. Lamb birth weight, weaning weight and mature weight was measured by weighing balance and values were recorded in $\mathrm{kg}$.

\subsection{Statistical analysis}

All data were stored in MS Excel and further analysis was done using SPSS IBM 20.0 version software program. The statistical analysis of the data was performed using compare mean with one way ANOVA and univariate analysis of variance procedure.

\section{Results}

\subsection{Age at first heat (puberty), pregnancy and lambing}

Age at first heat, pregnancy and lambing in indigenous ewes under traditional management system is shown in the Table 1 . The age at puberty or first heat varied from 150-300 days (5-10 months). The average age at first puberty was $193.4 \pm 22.6$ days in two regions. Ewe lambs in Mymensingh reached puberty at significantly $(\mathrm{P}<0.03)$ younger age $(186.9 \pm 18.4$ days $)$ than in Rajshahi $(199.9 \pm 24.9$ days $)$. The pooled over age at first lambing was 364.3 \pm 22.6 days in two regions. Similarly, the ewes in Mymensingh was lambing at early age than ewes in Rajshahi $(\mathrm{P}<0.002)(356.0 \pm 6.8$ days vs. $372.7 \pm 27.8$ days). The average age at first pregnancy was $201.4 \pm 20.0$ days in two regions. There was no significant difference in age at first pregnancy between the ewes of two different areas $(206.5 \pm 22.6$ vs. 196.2 \pm 15.8$)$.

Table 1. Comparison of age effects on reproductive parameters of ewes maintained under traditional management system.

\begin{tabular}{lllll}
\hline $\begin{array}{l}\text { Parameters } \\
\text { days) }\end{array}$ & \multicolumn{3}{c}{ Region } & $\begin{array}{l}\text { Level of } \\
\text { significance }\end{array}$ \\
\cline { 2 - 4 } & Rajshahi $(\mathbf{n = 2 6})$ & Mymensingh $(\mathbf{n = 2 6})$ & Pooled over data $(\mathbf{n = 5 2})$ & $(\mathrm{P}<0.03)$ \\
Age at first heat & $199.9 \pm 24.9^{\mathrm{a}}$ & $186.9 \pm 18.4^{\mathrm{b}}$ & $193.4 \pm 22.6$ & $\mathrm{NS}$ \\
$\begin{array}{l}\text { Age at first } \\
\text { pregnancy }\end{array}$ & $206.5 \pm 22.6$ & $196.2 \pm 15.8$ & $201.4 \pm 20.0$ & $(\mathrm{P}<0.002)$ \\
Age at first lambing & $372.7 \pm 27.8^{\mathrm{a}}$ & $356.0 \pm 6.8^{\mathrm{b}}$ & $364.3 \pm 22.6$ & \\
\hline
\end{tabular}

NS: Not significant, ${ }^{\text {a-b }}$ Mean values having different superscripts in a row differ significantly $(\mathrm{P}<0.05)$

\subsection{Oestrus duration and onset of post-partum heat (estrus)}

The duration of oestrus, onset of post-partum heat (estrus) and post-partum heat period are shown in Table 2 . Duration of oestrus in the present study varied from 24 to $36 \mathrm{hrs}$. The pooled over duration of oestrus was $36.0 \pm 8.2$ hours in two regions. There was no significant difference $(\mathrm{P}>0.05)$ in duration of oestrus in indigenous ewes between Rajshahi and Mymensingh. The observed duration of oestrus was $36.0 \pm 6.7 \mathrm{hrs}$ and $36.0 \pm 7.3 \mathrm{hrs}$, respectively. Onset of post-partum heat (estrus) was not significant $(\mathrm{P}>0.05)$ in Rajshahi and Mymensingh (26.0 \pm 11.1 vs. $24.3 \pm 9.9$ days).

Table 2. Comparison of reproductive parameters of ewes between two regions.

\begin{tabular}{lllll}
\hline \multirow{2}{*}{ Parameters } & \multicolumn{2}{c}{ Region } \\
\cline { 2 - 5 } & $\begin{array}{l}\text { Rajshahi } \\
(\mathbf{n = 2 6 )}\end{array}$ & $\begin{array}{l}\text { Mymensingh } \\
(\mathbf{n = 2 6})\end{array}$ & $\begin{array}{l}\text { Pooled over data } \\
(\mathbf{n = 5 2})\end{array}$ & $\begin{array}{l}\text { Level of } \\
\text { significance }\end{array}$ \\
\hline Duration of estrus (hrs.) & $36.0 \pm 6.7$ & $36.0 \pm 7.3$ & $36.0 \pm 8.2$ & $\mathrm{NS}$ \\
Gestation length (days) & $148.7 \pm 3.4$ & $147.1 \pm 3.2$ & $147.9 \pm 3.4$ & $\mathrm{NS}$ \\
Litter size & $1.7 \pm 0.2$ & $1.6 \pm 0.2$ & $1.6 \pm 0.2$ & $\mathrm{NS}$ \\
Lambing interval & $197.9 \pm 24.9$ & $189.8 \pm 16.7$ & $193.9 \pm 21.7$ & $\mathrm{NS}$ \\
On Onset of post-partum heat (days) & $26.0 \pm 11.1$ & $24.3 \pm 9.9$ & $25.2 \pm 10.4$ & $\mathrm{NS}$ \\
\hline
\end{tabular}

NS- Not significant. 
3.3. Gestation length, litter size and lambing interval

The gestation length, litter size and lambing interval in indigenous ewes is placed in Table 2. The gestation length varied from 145 to 150 days. The average gestation length was $147.9 \pm 3.4$ days in two regions. The gestation length was not significant $(\mathrm{P}>0.05)$ in the ewes between Rajshahi and Mymensingh (148.7 \pm 3.4 and 147.1 \pm 3.2 days; respectively). The pooled over litter size was $1.6 \pm 0.2$ in two regions. However, there was no significant $(\mathrm{P}>0.05)$ difference in litter size of ewes in Rajshahi and Mymensingh region $(1.7 \pm 0.2$ vs. 1.6 \pm 0.2$)$. Also there was no significant $(\mathrm{P}>0.05)$ difference in lambing interval of ewes in Rajshahi and Mymensingh region (197.9 \pm 24.9 vs. $189.8 \pm 16.7$ days). The pooled lambing interval was $193.9 \pm 21.7$ days in two regions.

\subsection{Birth weight of lambs, weaning weight and mature weight}

Lamb birth weight, weaning weight of lamb and mature weight from this study are presented in Table 3. Mean birth weights of lambs were $1.7 \pm 0.6 \mathrm{~kg}$ and $1.3 \pm 0.1 \mathrm{~kg}$ in Rajshahi and Mymensingh, respectively. The birth weight of lambs in Rajshahi were significantly higher $(\mathrm{P}<0.001)$ compared with lambs born in Mymensingh. However, the pooled over birth weight of lambs was $1.5 \pm 0.5 \mathrm{~kg}$ in two regions. The weaning weight were significantly higher $(\mathrm{P}<0.001)$ of lambs born in Rajshahi $(8.9 \pm 2.7 \mathrm{~kg})$ compared with Mymensingh $(6.9 \pm 1.0$ $\mathrm{kg})$. The mature weight were also significantly higher $(\mathrm{P}<0.001)$ in Rajshahi $(24.9 \pm 7.3 \mathrm{~kg})$ compared with Mymensingh $(19.4 \pm 2.7 \mathrm{~kg})$.

Table 3. Growth performance of indigenous sheep at field level (Mean \pm SD).

\begin{tabular}{lllll}
\hline $\begin{array}{l}\text { Parameters } \\
(\mathbf{k g})\end{array}$ & \multicolumn{3}{c}{ Region } & $\begin{array}{l}\text { Level of } \\
\text { significance }\end{array}$ \\
\cline { 2 - 5 } & $\begin{array}{l}\text { Rajshahi } \\
(\mathbf{n = 2 6 )}\end{array}$ & $\begin{array}{l}\text { Mymensingh } \\
(\mathbf{n = 2 6 )}\end{array}$ & $\begin{array}{l}\text { Pooled over data } \\
(\mathbf{n = 5 2})\end{array}$ & $(\mathrm{P}<0.001)$ \\
\hline Lamb birth weight & $1.7 \pm 0.6^{\mathrm{a}}$ & $1.3 \pm 0.1^{\mathrm{b}}$ & $1.5 \pm 0.5$ & $(\mathrm{P}<0.001)$ \\
Weaning weight of lamb & $8.9 \pm 2.7^{\mathrm{a}}$ & $6.9 \pm 1.0^{\mathrm{b}}$ & $7.9 \pm 2.2$ & $(\mathrm{P}<0.001)$ \\
Mature weight & $24.9 \pm 7.3^{\mathrm{a}}$ & $19.4 \pm 2.7^{\mathrm{b}}$ & $22.2 \pm 6.2$ & 0 \\
\hline
\end{tabular}

${ }^{\mathrm{a}-\mathrm{b}}$ Mean values having different superscripts in a row differ significantly $(\mathrm{P}<0.001)$

\section{Discussion}

The age effects of puberty, first pregnancy and first lambing in ewes maintained under traditional management system were observed in two regions in Bangladesh. The age at puberty or first heat varied from 150 to 300 days (5 to 10 months). According to the opinions of sheep farmers in Rajshahi division that indigenous ewes show heat or oestrus at earlier age compared with the Garole ewes. The present observation is more or less similar with the study of other researcher, 5 and 12 months required to reached puberty (Schoenian, 2014); 28.2 \pm 0.8 weeks (Souza et al., 2010); 6 to 9 months (Changjun, 2013) 6.22 \pm 1.31 months and group 8.43 \pm 1.15 months (Zohara et al., 2014). Therefore the difference between reproductive performances in Rajshahi and Mymensingh division could be due to breed, feeding and climatic condition of the region. In traditional management system both Rajshahi and Mymensingh division may have an positive effect which resulted no difference from the study of Zohara et al. (2014); where the sheep were maintained in good management system in research station.

In present study, the average age at first lambing was 364.3 \pm 22.6 days in two regions. The ewes in Mymensingh were lambing at early age than ewes in Rajshahi. The present observation is similar in Barind sheep, $389.9 \pm$ 43.0 days and Jamuna basin sheep, $409.8 \pm 75.0$ days (Hassan and Talukder, 2011). In other studies, the age at first lambing was $530.5 \pm 12.4$ days in Munjal sheep (Poonia, 2008), higher than the present findings.

The average age at first pregnancy was $201.4 \pm 20.0$ days in two regions. There was no significant difference in age at first pregnancy between the ewes of two different areas. The present observation is similar with the age of first pregnancy in Jamuna basin sheep, 277.0 \pm 104.9 days, Barind sheep, 264.7 \pm 49.4 days and Costal sheep, 292.3 \pm 47.5 days (Hassan and Talukder, 2011) performed in Bangladesh Livestock Research Institute (BLRI) research station.

The reproductive parameters viz, duration of oestrus, gestation length, litter size, lambing interval and onset of post-partum oestrus were observed in Rajshahi and Mymensingh division also supported with Zohara et al., 2014. In traditional management system, the gestation length in ewes varied from 145 to 152 days. In the present study pooled over gestation length was $147.9 \pm 3.4$ days in two regions. Similar with above parameters gestation length in ewes was also not significantly $(\mathrm{P}>0.05)$ different between Rajshahi and Mymensingh (148.7 \pm 3.4 vs. $147.1 \pm 3.2$ days), respectively. The present study is supported by Timurkan and Yildiz (2005); Husain and Amin (2003) and Zohara et al. (2014). 
The average litter size was $1.6 \pm 0.2$ in two regions and is supported by other researcher in Garole sheep (Sharma et al., 1999); in controlled, ewes (Zohara et al., 2014; Nimbkar et al., 2002). These observations indicate that average litter size is more or less similar (1 or 2 commonly, rearly 3) among the sheep breeds of tropical countries in well managed condition. No significant $(\mathrm{P}>0.05)$ difference in lambing interval of ewes in Rajshahi and Mymensingh region (197.9 \pm 24.9 vs. $189.8 \pm 16.7$ days). It is supported by Hassan and Talukder, (2011) observed in Jamuna, Barind and Coastal sheep. Nimbkar et al. (2002) found in Deccani sheep in India that the average lambing interval was $264.0 \pm 81.0$ days, higher than the present findings. This could be due to differences in breed, nutrition and environment of the study region.

Mean birth weights of lambs were $1.7 \pm 0.6 \mathrm{~kg}$ and $1.3 \pm 0.1 \mathrm{~kg}$ in Rajshahi and Mymensingh, respectively. Researchers found that, lamb birth weight $1.2 \mathrm{~kg}$ (Husain and Amin, 2003) and $1.00 \pm 0.30$ and $1.33 \pm 0.25 \mathrm{~kg}$ in controlled and supplemented group (Zohara et al., 2014), which is more or less similar to the present study.

The mean weaning weight of indigenous lambs obtained in the current study was lighter than weaning weights of other breeds (Awgichew, 2000; Tibbo, 2006). The present study is supported by Zohara et al. (2014), supplemented groups compared with controlled groups $(3.58 \pm 0.93 \mathrm{~kg} \& 5.71 \pm 1.03 \mathrm{~kg}$, respectively) indicating no difference between confined rearing sheep and well managed traditional management system. Similarly, the mature body weight were also significantly higher $(\mathrm{P}<0.001)$ in sheep in Rajshahi $(24.9 \pm 7.3 \mathrm{~kg})$ compared with Mymensingh $(19.4 \pm 2.7 \mathrm{~kg}$ ). As stated above, this higher mature body weight could be due to breed effect.

\section{Conclusions}

From the above study it may be concluded that reproductive performances of indigenous sheep in research station is more or less similar with the well managed traditional rearing system. The differences in traditional management system between the farms results in difference in reproductive performances of ewes in two regions.

\section{Acknowledgements}

The authors are grateful to Yousuf Ali Sarker (YA Sarker) for data management and manuscript preparation. The authors are also grateful to the Bangladesh Academy of Science and United States Department of Agriculture (BAS-USDA; LS-02) for financial support.

\section{Conflict of interest}

None to declare.

\section{References}

Awgichew K, 2000. Comparative performance evaluation of Horro and Menz sheep of Ethiopia under grazing and intensive feeding conditions. PhD Thesis, Faculty of Agriculture and Horticulture, Humboldt University, Berlin, Germany pp. 6-22.

Bhuiyan AKFH, 2006, Livestock genetic resources in Bangladesh: Preservation and Management. International conference on livestock services, Chinese Academy of Agricultural Science (CAAS), Beijing, China, April $16-20$.

Changjun Z, 2013, Puberty Pathways to Pregnancy and Parturition, Sichuan Agricultural University 1-31.

DLS, 2016. Livestock Economy at a Glance 2015-2016. Directoate of Livestock Services, Bangladesh.

Hassan MR and MAI Talukder, 2011. Comparative performance of different regional native sheep in Bangladesh. The Bangladesh Veterinarian, 28: 85-94.

Husain SS and MR Amin, 2003. Genetic resource conservation and utilization: participatory maintenance of animal Genetics resource at rural level in Bangladesh. Paper presented Genetic resource conservation, Bangladesh Livestock Research Institute, Savar Dhaka, Bangladesh.

Nimbkar C, PM Ghalsasi, SW Walkden-Brown and LP Kahn, 2002. Breeding program for the genetic improvement of Deccani sheep of Maharashtra, India. 7th World Congress of Genetics Applied to Livestock Production, Montpellier, France. August 19-23.

Poonia JS, 2008. Reproductive performance of Munjal sheep. The Indian Journal of Small Ruminants, 14: 121123.

Sarker YA, AH Miah, N Sharif, MH Himel, S Islam, RC Ray, TK Paul, MT Islam and MH Sikder, 2015. A retrospective study of common diseases at veterinary teaching hospital, Bangladesh Agricultural University, Mymensingh. Bangl. J. Vet. Med., 13:55-61.

Schoenian S, 2014. Sheep 101. Http: //www.3heep101.info/201/ramrepro.html. 
Sharma RC, AL Arora, HK Narula and RN Singh, 1999. Characteristics of Garole sheep in India. Animal Genetic Resources Information, 26: 57-64.

Souza CEI, AA Araujo, II Oliveira, AC Lima Souza, IN Neiva and AA Moura, 2010. Reproductive development of Santa Ines rams during the first year of life: body and testis growth, testosterone concentrations, sperm parameters, age at puberty and seminal plasma proteins. Reproduction in Domestic Animals, 45: 644-53.

Tibbo M, 2006. Productivity and health of indigenous sheep breeds and crossbreds in the central Ethiopian highlands. PhD Thesis, Department of Animal Breeding and Genetics, Faculty for Veterinary Medicine and Animal Sciences, Swedish University of Agricultural Sciences, Uppsala, Sweden pp. 76.

Yildiz H and H Timurkan, 2005. Synchronization of oestrus in Hamdani Ewes: The use of Different PMSG Doses. Bulletin of the Veterinary Institute in Pulawy, 49: 311-314.

Zohara BF, Azizunnesa, MF Islam, MGS Alam and FY Bari, 2014. Reproductive Performances of Indigenous Ewes in Bangladesh. IOSR Journal of Agriculture and Veterinary Science, 7: 64-72. 